\title{
SIMULTANEOUS ESTIMATION, VALIDATION, AND FORCED DEGRADATION STUDIES OF BETAHISTINE DIHYDROCHLORIDE AND DOMPERIDONE IN A PHARMACEUTICAL DOSAGE FORM USING RP-HPLC METHOD
}

\author{
VAISHALI MISTRY*, ROHAN MISHRA \\ Department of Quality Assurance, Oriental College of Pharmacy, Sanpada, Navi Mumbai - 400 705, Maharashtra, India. \\ Email: vaishali.mistry@ocp.edu.in
}

Received: 22 March 2018, Revised and Accepted: 07 June 2018

ABSTRACT

Objective: This study describes the stability-indicating reverse-phase high-performance liquid chromatography (RP-HPLC) method for simultaneous estimation of betahistine dihydrochloride and domperidone in pharmaceutical dosage forms.

Methods: The proposed RP-HPLC method was developed using Shimadzu Prominence-i LC-2030 HPLC system equipped with UV detector and chromatographic operation was carried on Shim-pack C18 (250 mm×4.6 mm, $5 \mu$ ) column at a flow rate of $1 \mathrm{ml} / \mathrm{min}$ and the run time was $10 \mathrm{~min}$. The mobile phase consisted of methanol and water in the ratio of $80: 20 \% \mathrm{v} / \mathrm{v}$ and eluents were scanned using a UV detector at $244 \mathrm{~nm}$.

Results: The retention time of betahistine dihydrochloride and domperidone was found to be 2.3 and 3.6 min, respectively. A linearity response was observed in the concentration range of $9.6 \mu \mathrm{g} / \mathrm{ml}-22.4 \mu \mathrm{g} / \mathrm{ml}$ for betahistine dihydrochloride and $6-14 \mu \mathrm{g} / \mathrm{ml}$ for domperidone, respectively. Limit of detection and limit of quantification for betahistine dihydrochloride were $0.52 \mu \mathrm{g} / \mathrm{ml}$ and $1.58 \mu \mathrm{g} / \mathrm{ml}$ and for domperidone are $0.64 \mu \mathrm{g} / \mathrm{ml}$ and $1.94 \mu \mathrm{g} / \mathrm{ml}$, respectively.

Conclusion: The stability-indicating method was developed by subjecting drugs to stress conditions such as acid and base hydrolysis, oxidation, photo and thermal degradation, and degraded products formed were resolved successfully from samples.

Keywords: Betahistine dihydrochloride, Domperidone, Reverse-phase high-performance liquid chromatography, Degradation, Validation.

(C) 2018 The Authors. Published by Innovare Academic Sciences Pvt Ltd. This is an open access article under the CC BY license (http://creativecommons. org/licenses/by/4. 0/) DOI: http://dx.doi.org/10.22159/ajpcr.2018.v11i10.26132

\section{INTRODUCTION}

Betahistine dihydrochloride (Fig. 1) is chemically N-methyl-2pyridine-ethanamine, a well-known antivertigo drug [1]. It is official in Indian Pharmacopoeia [2], the British Pharmacopoeia [3], European Pharmacopeia [4], and the United States Pharmacopeia (USP) [5]. It possesses affinity as an antagonist of $\mathrm{H}_{3}$ receptors and a weak affinity as an agonist for $\mathrm{H}_{1}$ receptors. The active ingredient is a mainly a histamine agonist with no $\mathrm{H}_{2}$ activity.

Domperidone (Fig. 2) 5-chloro-1-[1-[3-(2-0xo-2,3-dihydro-1Hbenzi midazol-1-yl) propyl]-piperidin-4-yl]-1,3-dihydro-2H benzimidazol2-one acts by selectively antagonizing the peripheral dopaminergic $\mathrm{D}_{2}$ receptors in the gastrointestinal wall, thereby enhancing gastrointestinal peristalsis and motility and increasing lower esophageal sphincter tone. It is a dopamine (D2) receptor antagonist. DMP is used for the treatment and prevention of acute nausea and vomiting of any cause, especially cytotoxic therapy and radiotherapy. According to Biopharmaceutical Classification System, DMP is classified under Class-II drugs which are poorly soluble and highly permeable [6].

Literature survey reveals high-performance liquid chromatography (HPLC) for estimation of betahistine dihydrochloride and domperidone and is not available for pharmaceutical dosage form. Therefore, the present study was carried out to develop novel, simple, precise, rapid, and costeffective RP-HPLC method for the simultaneous estimation of betahistine dihydrochloride and domperidone in pharmaceutical dosage form $[7,8]$.

\section{METHODS}

Betahistine dihydrochloride and domperidone standard were provided by Clearsynth Labs Ltd., Mumbai, Maharashtra, India, and Indoco
Remedies, Navi Mumbai, Maharashtra, India. Commercial tablet dosage form VERTISTAR PLUS was purchased from local markets. The HPLC-grade methanol and water were purchased from Thomas Fisher Scientific Pvt., Ltd., Powai, Mumbai, Maharashtra, India. Hydrochloric acid, sodium hydroxide, and hydrogen peroxide were purchased from S.D. Fine Chemicals.

\section{HPLC instrument}

The chromatographic separation was carried out by Shimadzu prominence-i LC-2030 HPLC system equipped with UV detector and autosampler. The Software Lab solution was used for signal monitoring and processing, UV chamber has been used for photolytic degradation, and hot air oven was employed for thermal degradation.

\section{Chromatographic conditions}

The chromatographic separation of analytes was carried out using Shimadzu reverse-phase (RP)-HPLC system with Shim-pack GIST C18 $(250 \times 4.6 \mathrm{~mm})$ column. The mobile phase consists of water and methanol in the ratio of $20: 80 \% \mathrm{v} / \mathrm{v}$, and column temperature was maintained at $40^{\circ} \mathrm{C}$. The analytes were detected at $244 \mathrm{~nm}$ using UV detector. The run time was set at $10 \mathrm{~min}$ at a flow rate of $1 \mathrm{ml} / \mathrm{min}$.

\section{Preparation of standard stock solution}

Standard stock solution of betahistine dihydrochloride and domperidone was prepared separately by dissolving $100 \mathrm{mg}$ of betahistine dihydrochloride and $100 \mathrm{mg}$ of domperidone in $100 \mathrm{ml}$ of volumetric flask with water:methanol (20:80) as diluents and sonicated for $10 \mathrm{~min}$. From the above solution, $0.16 \mathrm{ml}$ of betahistine dihydrochloride and $0.1 \mathrm{ml}$ of domperidone were transferred separately to $10 \mathrm{ml}$ volumetric flask, made up the volume to get $16 \mu \mathrm{g} / \mathrm{ml}$ and $10 \mu \mathrm{g} / \mathrm{ml}$ of stock solution of betahistine dihydrochloride and domperidone, respectively. 
Preparation of sample solution

10 tablets (Vertistar Plus tablet; $16 \mathrm{mg}$ betahistine dihydrochloride and $10 \mathrm{mg}$ domperidone) were weighed and the average weight of each tablet was calculated; then, the weight equivalent to 10 tablets was transferred into $100 \mathrm{ml}$ volumetric flask; $50 \mathrm{ml}$ of diluents was added and sonicated for $30 \mathrm{~m}$; further, the volume made up with diluents and filtered. From the filtered solution, $1 \mathrm{ml}$ was pipette out into $10 \mathrm{ml}$ volumetric flask and sonicated for $10 \mathrm{~min}$, and volume made up to $10 \mathrm{ml}$ with diluents.

\section{Forced degradation studies}

Forced degradation studies $[9,10]$ of the drug formulation were carried out by treating the drug samples under stress-induced conditions such as acid, base hydrolysis, oxidation, humidity, photodegradation, and thermal degradation. These studies help to know the inherent stability characteristic of the active molecule in drug product and possible degradation products.

\section{Acid degradation}

Acidic degradation was carried out by adding $5 \mathrm{ml}$ of $1 \mathrm{~N} \mathrm{HCl}$ to sample solutions and after $60 \mathrm{~min}$ neutralizing the mixture by adding $5 \mathrm{ml}$ of $1 \mathrm{~N} \mathrm{NaOH}$.

\section{Alkali degradation}

Alkali degradation was carried out by adding $5 \mathrm{ml}$ of $1 \mathrm{~N} \mathrm{NaOH}$ and after 60 min neutralizing the mixture by adding $5 \mathrm{ml}$ of $1 \mathrm{~N} \mathrm{HCl}$.

\section{Oxidative degradation}

Oxidative degradation was performed by exposing the drug to $5 \mathrm{ml}$ of $10 \%(\mathrm{v} / \mathrm{v}) \mathrm{H}_{2} \mathrm{O}_{2}$ for 60 min.

\section{Photolytic degradation}

Photolytic degradation was carried out by exposing the drug content to UV light inside a UV chamber for 2 days.

\section{Thermal degradation}

Thermal degradation was performed by placing the drug in an oven at $95^{\circ} \mathrm{C}$ for $24 \mathrm{~h}$ to study dry heat degradation.

\section{Statistical analysis}

To evaluate the contribution of each factor with different levels of responses, two-way analysis of variance was performed using GraphPad Prism 7.04 software.

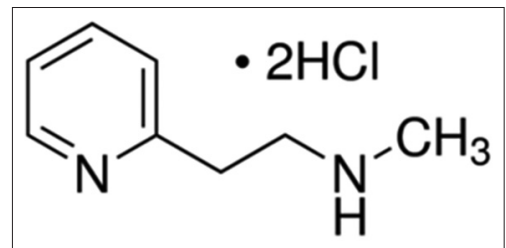

Fig. 1: Betahistine dihydrochloride

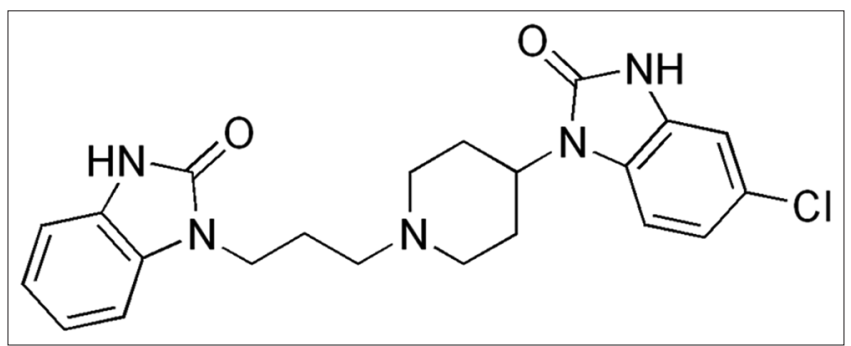

Fig. 2: Domperidone

\section{RESULTS AND DISCUSSION}

\section{Method development}

Using different columns, a series of trials was conducted, with different mobile phases to develop suitable RP-HPLC method for estimation of betahistine dihydrochloride and domperidone in tablet dosage form, and finally, a typical chromatogram was obtained with water and methanol in the ratio of 20:80\% v/v. The chromatographic separation was performed on Shim-pack C-18 (250 mm×4.6 mm, $5 \mu$ ) column, on injecting $10 \mu \mathrm{L}$ and the analytes were detected with UV detector at $244 \mathrm{~nm}$. The retention time of betahistine dihydrochloride and domperidone was found to be $2.3 \mathrm{~min}$ and $3.6 \mathrm{~min}$, respectively. The force degradation study was also carried out using developed method. The optimized conditions were given in Table 1.

\section{Method validation}

The validation was performed with above developed RP-HPLC method for simultaneous estimation of betahistine dihydrochloride and domperidone according to ICH guidelines. Various parameters were evaluated such as system suitability, precision, accuracy, linearity, robustness, limit of detection (LOD), and limit of quantification (LOQ).

\section{System suitability}

System suitability was conducted to verify the acceptability of the resolution and repeatability of the system. System suitability was performed by injecting six replicate injections of the standard solution (100\%) (Fig. 3) and parameters such as peak area, USP tailing, theoretical plates, retention time, and peak asymmetry were evaluated. The percentage relative standard deviation (RSD) was determined and reported within the limits (Table 2).

\section{Accuracy}

The accuracy of the proposed method was evaluated by calculating the recovery studies of the test drug at three different concentration levels $(80 \%, 100 \%$, and $120 \%)$ by the standard addition method. A known amount of betahistine dihydrochloride and domperidone was added to the pre-quantified sample solution, and three replicates of each concentration were injected into developing chromatographic conditions. The mean percentage recovery of betahistine dihydrochloride and domperidone was varied between 99.2 and $100.8 \%$ indicating that the developed method was found to be accurate (Table 3).

\section{Precision}

The precision of an analytical procedure may be defined as the closeness of agreement between a series of measurements obtained from multiple sampling of the same homogeneous sample under the

Table 1: Optimized chromatographic conditions

\begin{tabular}{|c|c|c|}
\hline S. No. & Parameter & Optimized conditions \\
\hline 1 & Column & $\begin{array}{l}\text { Shim-pack C-18 }(250 \mathrm{~mm} \times 4.6 \mathrm{~mm}, 5 \mu) \\
\text { column }\end{array}$ \\
\hline 2 & Mobile phase & Methanol and water 80:20 \\
\hline 3 & Flow rate & $1 \mathrm{ml} / \mathrm{min}$ \\
\hline 4 & Wavelength & UV detector $244 \mathrm{~nm}$ \\
\hline 5 & Injection volume & $10 \mu \mathrm{L}$ \\
\hline 6 & Temperature & $40^{\circ} \mathrm{C}$ \\
\hline 7 & Retention time & $\begin{array}{l}\text { Betahistine dihydrochloride } 2.3 \mathrm{~min} \\
\text { and domperidone } 3.6 \mathrm{~min}\end{array}$ \\
\hline
\end{tabular}

Table 2: System suitability parameters

\begin{tabular}{llll}
\hline S. No & Parameters & $\begin{array}{l}\text { Betahistine } \\
\text { dihydrochloride }\end{array}$ & Domperidone \\
\hline 1 & Retention time & 2.3 & 3.6 \\
2 & USP plate count & 4890 & 2059 \\
3 & USP tailing & 1.39 & 1.61 \\
\hline
\end{tabular}


Table 3: Percentage recovery results of betahistine dihydrochloride and domperidone

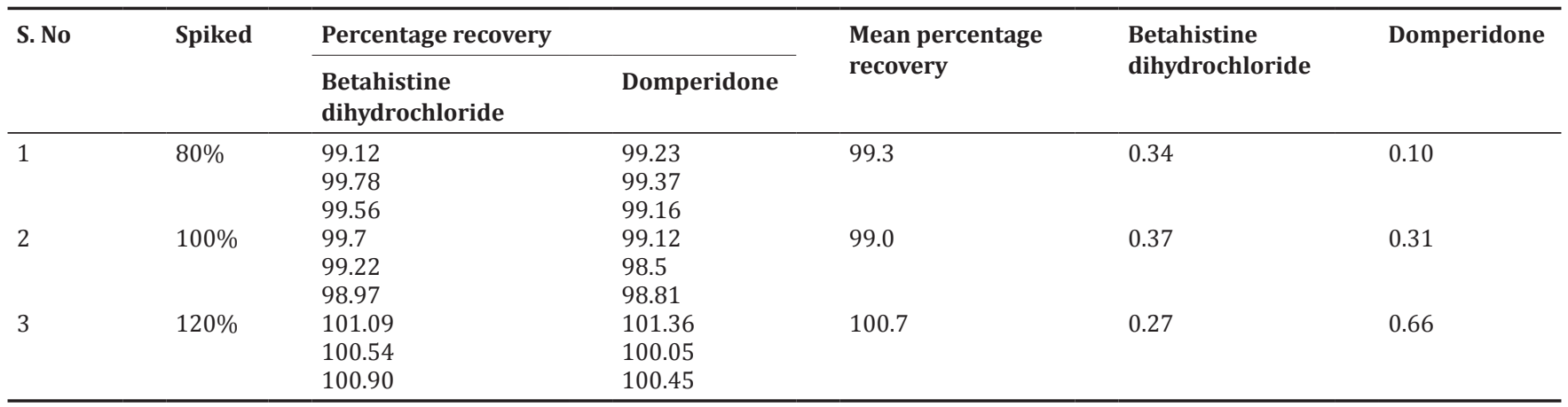

prescribed conditions. The method precision and system precision studies were carried out by injecting six replicates of both standard and test solutions with the same concentration. The percentage RSD was calculated from the chromatograms, and the results obtained were within the limits of $2 \%$ and proposed method was found to be precise (Table 4).

\section{Linearity}

The linearity of the method was determined at different concentration levels ranging from 6 to $14 \mu \mathrm{g} / \mathrm{ml}$ of betahistine dihydrochloride and from 9.2 to $22.4 \mu \mathrm{g} / \mathrm{ml}$ of domperidone. All the concentrations were prepared and injected into the system. The linearity curve was constructed by plotting peak area versus concentration of the analyte. From the results obtained, the proposed method was found to be linear. The regression coefficient was found to be 0.998 and 0.998 for betahistine dihydrochloride and domperidone, respectively (Fig. 4).

\section{LOD and LOQ}

In the present study, the LOD and LOQ betahistine dihydrochloride and domperidone were evaluated based on the standard calibration curve method. LOD is performed to know the lowest concentration level of the analytes that give a measurable response. LOD and LOQ for betahistine dihydrochloride are $0.52 \mu \mathrm{g} / \mathrm{ml}$ and $1.58 \mu \mathrm{g} / \mathrm{ml}$ and for domperidone are $0.64 \mu \mathrm{g} / \mathrm{ml}$ and $1.94 \mu \mathrm{g} / \mathrm{ml}$, respectively.

\section{Robustness}

Robustness of the proposed method has been evaluated by small deliberate changes in the system parameters such as flow rate, wavelength, and temperature. It was found that none of the above parameters caused alteration in the peak area, retention time, and USP tailing by small changes such as $\pm 0.2 \mathrm{ml}$ change in flow rate, $\pm 2 \mathrm{~nm}$ wavelength, and $\pm 2^{\circ} \mathrm{C}$ change in temperature. The percentage RSD was found to be within the limits and the method was found to be robust (Table 5).

\section{Assay of marketed formulation}

Analysis of the marketed formulation (Vertistar plus tablets: betahistine dihydrochloride is $16 \mathrm{mg}$ and domperidone is $10 \mathrm{mg}$ ) was purchased from local markets. 10 tablets weighed and average weight was calculated; weight equivalent to 10 tablets was transferred into $100 \mathrm{ml}$ volumetric flask, $50 \mathrm{ml}$ of diluents was added and sonicated for $30 \mathrm{~min}$, and further volume was made up with diluents and filtered. From filtered solution, $1 \mathrm{ml}$ was pipette out into $10 \mathrm{ml}$ volumetric flask and made up to $10 \mathrm{ml}$ with diluents. From the resulting solution, $10 \mu \mathrm{L}$ was injected into HPLC system and peak areas were recorded. The percentage assay of the marketed formulation was found to be 98.7 for betahistine dihydrochloride and 98.6 for domperidone (Table 6).

\section{Forced degradation studies}

ICH degradation was attempted to various stress conditions such as acid hydrolysis (using $1 \mathrm{~N} \mathrm{HCl}$ ), base hydrolysis (using $1 \mathrm{~N} \mathrm{NaOH}$ ), oxidative hydrolysis (using $5 \% \mathrm{H}_{2} \mathrm{O}_{2}$ ), thermal degradation (heated at
Table 4: Results of method precision for betahistine dihydrochloride and domperidone

\begin{tabular}{llll}
\hline S. No & Sample no & $\begin{array}{l}\text { Betahistine } \\
\text { dihydrochloride }\end{array}$ & Domperidone \\
\cline { 3 - 3 } & & \% assay & \% assay \\
\hline 1 & Injection 1 & 98.71 & \\
2 & Injection 2 & 98.37 & 99.43 \\
3 & Injection 3 & 99.72 & 98.67 \\
4 & Injection 4 & 98.59 & 98.21 \\
5 & Injection 5 & 98.47 & 99.48 \\
6 & Injection 6 & 98.30 & 98.54 \\
7 & Average & 98.70 & 98.30 \\
8 & SD & 0.52 & 98.77 \\
9 & \%RSD & 0.53 & 0.55 \\
\hline SD: Standard deviation RSD: Relative standard deviation &
\end{tabular}

Table 5: Results of robustness

\begin{tabular}{|c|c|c|c|c|c|c|c|}
\hline \multirow[t]{2}{*}{ S. No. } & \multirow[t]{2}{*}{ Parameters } & \multicolumn{3}{|c|}{$\begin{array}{l}\text { Betahistine } \\
\text { dihydrochloride }\end{array}$} & \multicolumn{3}{|c|}{ Domperidone } \\
\hline & & RT & NTP & $\mathrm{TF}$ & RT & NTP & TF \\
\hline \multirow[t]{2}{*}{1} & Flow rate $0.9 \mathrm{ml}$ & 2.6 & 5670 & 1.4 & 4.0 & 1999 & 1.8 \\
\hline & Flow rate a $1.1 \mathrm{ml}$ & 2.1 & 4550 & 1.4 & 3.3 & 1899 & 1.7 \\
\hline \multirow[t]{2}{*}{2} & Temperature 38 & 2.3 & 4951 & 1.5 & 3.6 & 2031 & 1.8 \\
\hline & Temperature 42 & 2.3 & 5008 & 1.4 & 3.6 & 1971 & 1.8 \\
\hline \multirow[t]{2}{*}{3} & Wavelength 242 & 2.3 & 5036 & 1.4 & 3.6 & 2013 & 1.79 \\
\hline & Wavelength 246 & 2.3 & 5093 & 1.4 & 3.6 & 2043 & 1.78 \\
\hline
\end{tabular}

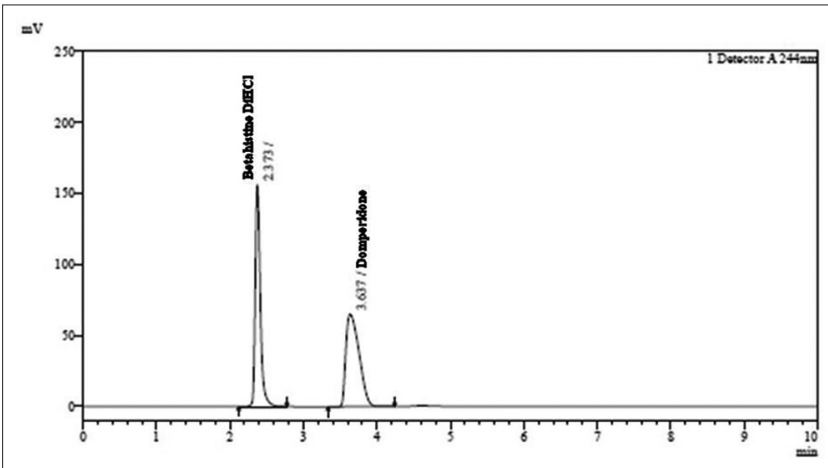

Fig. 3: Chromatogram of standard betahistine dihydrochloride and domperidone

$100^{\circ} \mathrm{C}$ for $24 \mathrm{~h}$ ), and photolytic degradation (using UV light inside a UV chamber for $24 \mathrm{~h}$ ). The results of stress studies were shown in Table 7 (Figs. 5-10). 
Table 6: Percent content of marketed formulation

\begin{tabular}{|c|c|c|c|c|c|}
\hline S. No. & Tablet & Drug & Amount taken & Amount found & \% assay \\
\hline \multirow[t]{2}{*}{1} & $\begin{array}{l}\text { Vertistar plus (betahistine dihydrochloride } \\
16 \mathrm{mg} \text { and domperidone } 10 \mathrm{mg} \text { ) }\end{array}$ & Betahistine dihydrochloride & 16 & 15.79 & 98.68 \\
\hline & & Domperidone & 10 & 9.94 & 99.4 \\
\hline
\end{tabular}

Table 7: Forced degradation studies of betahistine dihydrochloride and domperidone

\begin{tabular}{|c|c|c|c|c|c|}
\hline \multirow[t]{2}{*}{ S. No } & \multirow[t]{2}{*}{ Stress condition } & \multicolumn{2}{|c|}{ Betahistine dihydrochloride } & \multicolumn{2}{|c|}{ Domperidone } \\
\hline & & \%assay & $\%$ difference w.r.t control & \% assay & $\%$ difference w.r.t control \\
\hline 1 & Control & 98.6 & NA & 99.4 & NA \\
\hline 2 & Acid degradation & 87.77 & 12.22 & 88.47 & 11.52 \\
\hline 3 & Base degradation & 89.68 & 10.31 & 92.85 & 7.14 \\
\hline 4 & Oxidative degradation & 95.69 & 4.30 & 96.68 & 3.31 \\
\hline 5 & Photolytic degradation & 96.85 & 3.14 & 98.31 & 1.68 \\
\hline 6 & Thermal degradation & 98.26 & 1.73 & 98.88 & 1.11 \\
\hline
\end{tabular}

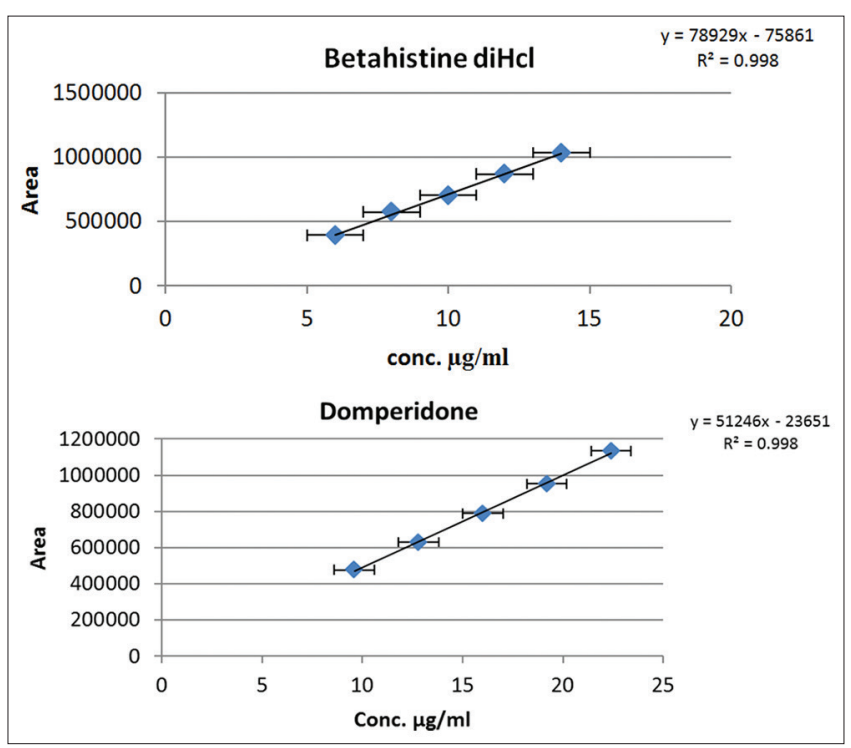

Fig. 4: Linearity graph of betahistine dihydrochloride and domperidone

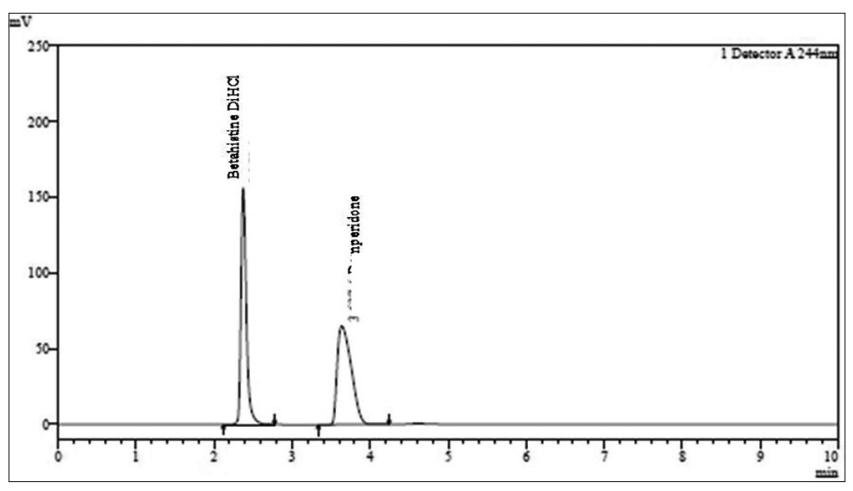

Fig. 5: Chromatograph of untreated tablet (sample)

\section{CONCLUSION}

In the present study, a stability-indicating RP-HPLC method has been developed and validated for simultaneous estimation of betahistine dihydrochloride and domperidone in tablet dosage form. The validated method was successfully used for stress testing, analysis of betahistine dihydrochloride and domperidone. The proposed method was proved

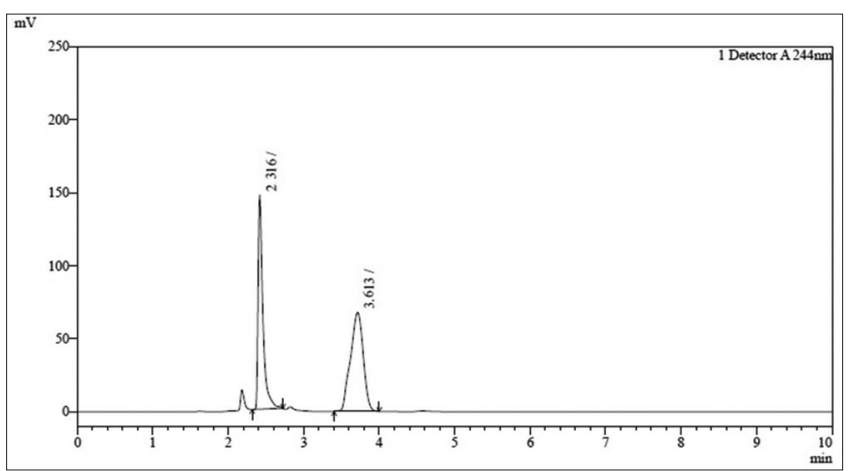

Fig. 6: Chromatograph of acid degradation

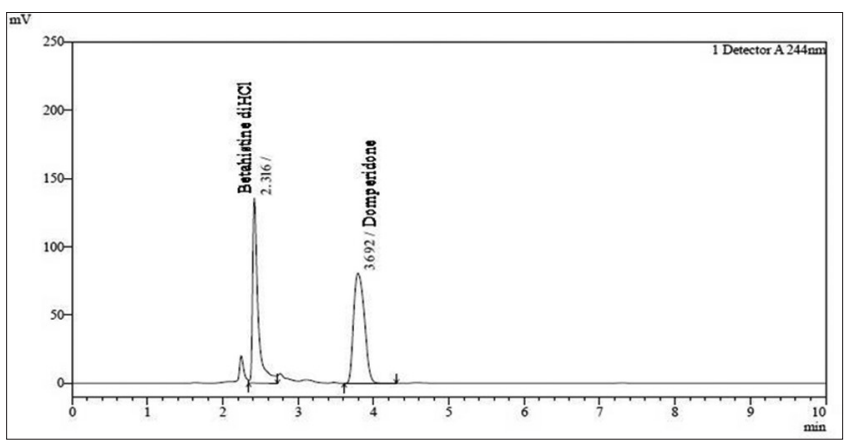

Fig. 7: Chromatograph of base degradation

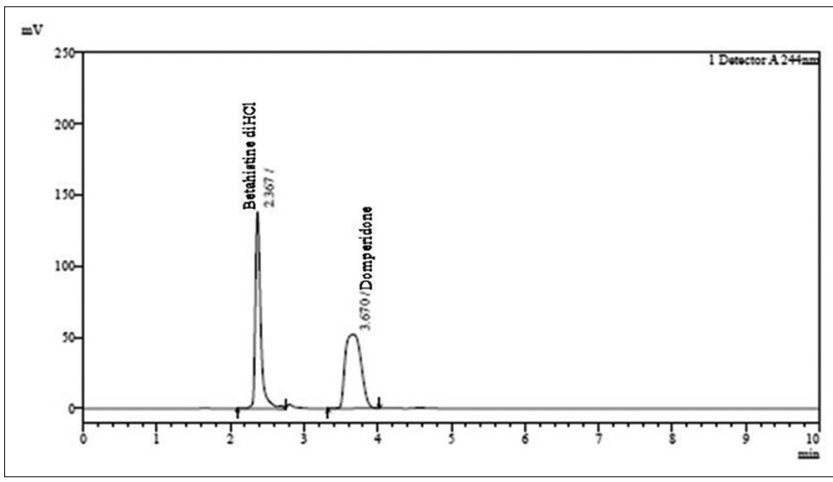

Fig. 8: Chromatograph of UV degradation 


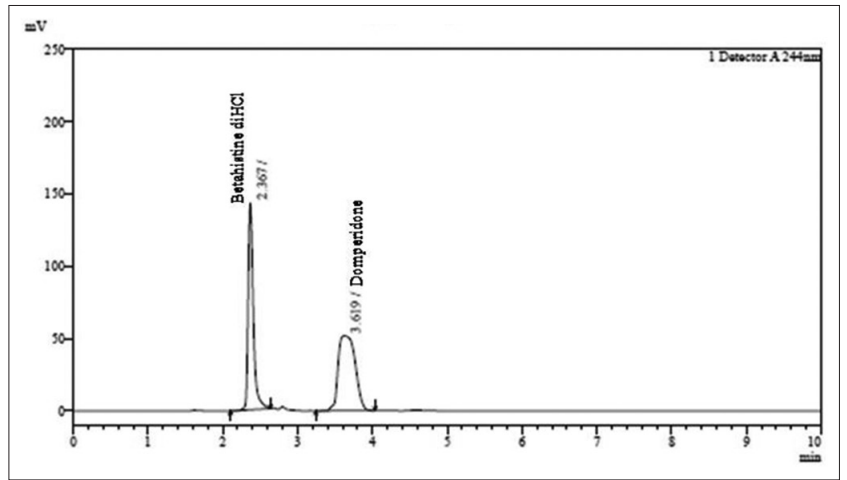

Fig. 9: Chromatograph of thermal degradation

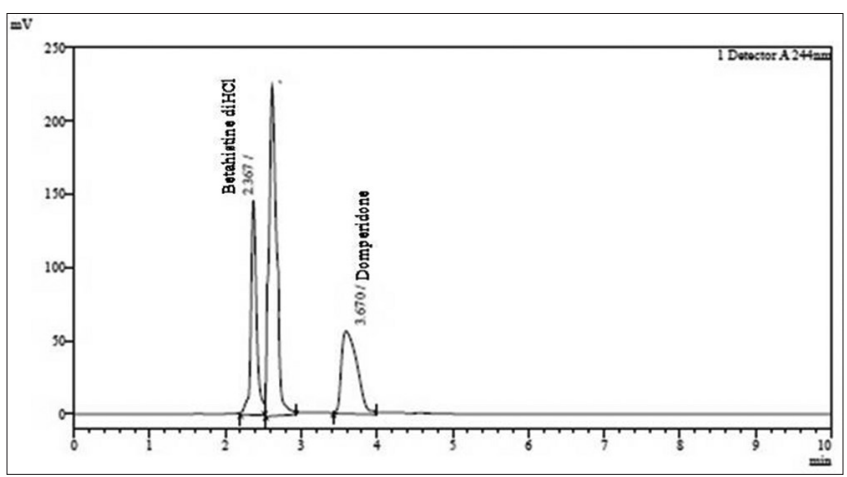

Fig. 10: Chromatograph of oxidative degradation

selective, accurate, precise, and rapid, and it can be used for the routine analysis of betahistine dihydrochloride and domperidone in formulation.

\section{ACKNOWLEDGMENT}

The authors are thankful to our principal Dr. Mrs. Sudha Rathod, Oriental College of Pharmacy, Sanpada, Navi Mumbai, for providing a platform and facility to conduct research work, the author Mr. Rohan Mishra would also like to thank Clearsynth Laboratories and Indoco
Remedies, for providing the sample of betahistine dihydrochloride and domperidone.

\section{AUTHOR'S CONTRIBUTION}

We declare that this study was performed by the authors mentioned in this article and all liabilities relating to claims relating to the substance of this article will be borne by the authors. Mr. Rohan Mishra collected the data, analyzed the data, all the laboratory work performed, and wrote the introduction, discussion, and the material and method part. Mrs. Vaishali Mistry contributed to designing and conducting the study, also proofread the whole manuscript.

\section{CONFLICTS OF INTEREST}

The authors declare that there are no conflicts of interest regarding the publication of this paper.

\section{REFERENCES}

1. O' Neil MJ, editor. Merck Index. $14^{\text {th }}$ ed. White House Station NJ: Merck and Co. Inc.; 2005. p. 1177

2. Govt of India. Indian Pharmacopoeia. Vol. II, $6^{\text {th }}$ ed. New Delhi: The Controller of Publication, Govt of India; 2010. p. 897-8.

3. London Medicines and Health Care Product Regulatory Agency. British Pharmacopoeia. Vol. I. London: Stationary Office, London Medicines and Health Care Product Regulatory Agency; 2010. p. 254-5.

4. Council of Europe. European Pharmacopoeia 6.0. Vol. II. 6 ${ }^{\text {th }}$ ed. Starboary: Council of Europe; 2008. p. 1292.

5. U.S. Pharmacopoeia/NF. Vol II. Twinbrook Pathway Rockvillae: The United States Pharmacpoeial Convention; 2013. p. 2635.

6. Aboutaleb AE, Abdel-Rahman SI, Ahmed MO, Younis MA. Design and evaluation of domperidone sublingual tablets. Int J Pharm Pharm Sci ISSN 2016;8:975-1491.

7. Praseetha K, kathirvel SR. Development and validation of RP-HPLC method for betahistine dihydrochloride in pharmaceutical dosage form. J Pharm Search 2014;9:621-5370.

8. Suparna S, Kumar SA. RP-HPLC method development and validation of domperidone in solid dosage form. Pharma Innov 2012;1:2277-7695.

9. Moinuddin M, Rahaman A, Yadav R, Battu R. Development and validation of RP-HPLC for simultaneous estimation of rosuvastatin calcium and fenofibrate in tablet dosage form. Int J Pharm Pharm Sci 2012;4 Suppl 3:975-1491.

10. Patil R, Deshmukh T, Patil V. Stability indicating HPLC method for dapoxetinehcl in bulk and in formulation. Int $\mathrm{J}$ Pharm Pharm Sci 2014;6:975-1491. 